\title{
Moslem Arab Portrayal in the Australian Press and in
}

\author{
School Textbooks
}

\begin{abstract}
Abe W. Ata
Abstract: This paper surveys the overall characterisation of Moslem Arabs and their culture as reflected by the press and in social science textbooks. Four widely circulated Melbourne newspapers and 15 of the most commonly used social science school textbooks formed the basis of content analysis. It has been found that the portrayal of Moslem Arabs was predominantly negative, involving overstatements, baseless charges and evaluative perceptions.
\end{abstract}

Key Words: Australian Muslims - portrayal; Arab ethnicity; media representation; school textbook representation; stereotypes; prejudices; racism

$\mathbf{F}$

or decades, the overall treatment of Moslem Arabs in both primary and secondary Australian textbooks as well as in the Australian press has created a raw-boned, faulty image, brought about by inaccurate, distorted or incomplete information. As yet, Moslem Arabs have rarely been portrayed in a commendable or positive manner, one that is predisposed towards enhancement of their culture. Instead, the sense of antipathy has, in one form or another, perpetuated a historically-orientated stereotype. In brief, the treatment has generally been a pot-pourri of prejudices, incorrect data, and omissions. A journalist asks:

What's the difference between an Iranian, an Arab or an Iranian Arab? It's a question that has confused many people since the London hostage siege broke out. Aren't they all Moslems and from the same region? So what are they fighting about? Well, one of the biggest insults you can pay to an Iranian is to call him an Arab. ${ }^{1}$

Such misnomers were inflicted by the Bureau of Statistics in 1971, when it combined Iraqi and Iranian nationals in one category, though it did separate them in 1976. At the same time, Arab countries west of Egypt were combined with certain African countries in "Other Africa."

\section{Methodological Procedure}

This study involved the selection of two sets of samples for content analysis. The first consisted of the four most widely circulated newspapers in Melbourne: The Herald, The Age, The Australian and The Sun News Pictorial, covering the period from 1 January1976 to 30 December 1980. This coverage was influenced by the fact that very little was found before 1976 to warrant investigation. Every seventeenth issue of each of the newspapers was selected for analysis. This procedure resulted in a total of 435 issues being examined, with an average of 109 issues selected from each paper. Items were selected from most

\footnotetext{
1 The Sun, 3 May 1980
} 
sections of the papers (such as feature articles, letters to the editor, editorials and news items) although the sports section and advertisements were discarded.

The criteria selected for inclusion of a newspaper article in the sample for analysis included mention of any of the following issues: Moslem religious affiliation; national affiliation to Arab Middle Eastern countries; Arab-Moslem institutions in Australia (economic, social, cultural, ethnic, individually or group-based); Government policies and community attitudes; book designs, photos and other stereotypical motifs on Arabs, Moslems or Bedouins.

The second of the sample sets was based on 15 of the most common social studies textbooks used as resource material in both upper primary and lower secondary schools (see Appendix). These books were selected from 20 State and private schools in Melbourne. The obvious reason for selecting books as a unit of analysis is their subliminal impact on attitude formation, as evidenced in recent socio-psychological studies, often reported in Psychological Abstracts, Psychological Bulletin and Psychological Review. In the overall analysis, certain 'pointers' were included. For example, the category of 'negative descriptions' included items viewed as conflicting with or undesirable to the host culture. The definition of these pointers sharpened with the progress of analysis to include additional ones. For instance, evaluation of the family structure of Arab migrants as 'unnecessarily large' was treated as a negative.

\section{Content Analysis}

The main image communicated in both press articles and in the text books was confined to five basic subjects, with only a small range of difference in the frequency of references in evidence (see Table 1).

Table 1: Value References of Moslem Arabs in the Australian Press between January 1976 and December 1980

\begin{tabular}{|l|l|l|l|}
\hline Value Reference & $\begin{array}{l}\text { No. of } \\
\text { Articles }\end{array}$ & $\%$ \\
\hline $\begin{array}{l}\text { Favourable Evaluation: } \\
\text { Pointers included items such as 'assimilated', 'like us', } \\
\text { 'acceptable' }\end{array}$ & 41 & 12.5 \\
\hline $\begin{array}{l}\text { Unfavourable Evaluation: } \\
\text { Pointers included items such as 'threatening', 'strangers', } \\
\text { 'inferior' }\end{array}$ & 155 & 11.6 \\
\hline \begin{tabular}{l|l|l|} 
No Evaluation \\
Pointers included items such as 'different'
\end{tabular} & 38 & 28.5 \\
\hline $\begin{array}{l}\text { Division amongst Christian-Moslem Arabs } \\
\text { (both in Australia and the Middle East) }\end{array}$ & 327 & 100.0 \\
\hline TOTAL & 93 & \\
\hline
\end{tabular}

Note: Based on 435 articles with each having a possible reference to more than one category. 


\section{Culture, Race and Nomadism}

One of the perennial and stereotyped images of the Arab is that of a camel-riding nomad: a caricature which embodies backwardness and illiteracy. As recently as the late 1950's Ellis writes on Arab life:

Soon the last animal had filed over the dunes, and the hollow was empty, with only the smoking remains of the camel dung fires as evidence that Arabs had been there. ${ }^{2}$

Though a few of the books examined state that up to 28 percent of Arabs are Bedouins, primitive and backward (the actual figure is less than 9 percent), Arab governments have provided permanent settlements for most Bedouins.

Yet Ellis contends that:

...all over Arabia [people] moved about the desert to satisfy the needs of their animals and men [note the association]. This is the nomad way of life in desert Arab as it has been for thousands of years. ${ }^{3}$

Fichter also observes the following:

Arabia has given up its people again and again to the lands of the north, where the rude Semitic nomads had [finally] mingled with the settled people. ${ }^{4}$

The anti-Semitic Jewish characteristics of a long, hooked nose, an evil moustache, and a dark beard have been successfully transferred to the Arab.

Of the 15 books surveyed, seven contained book-covers with sketches of ghost-like shadows of an Arab man or woman. This image is reinforced further in not too subtle statements such as:

...[Arabs] wear modern suits and skirts, and except for their dark skins and obvious Arabic features, they could easily pass for Europeans. ${ }^{5}$

The Age, under the headline "Sobering Up the Arabs" reported:

A Riverina company has found a multi-million dollar market - non-alcoholic wine to Moslems... Any other kind has to be coloured or easily becomes alcoholic. We don't want to start a diplomatic incident, or a third world war. ${ }^{6}$

Says Lengyel:

It is estimated that an average Egyptian employee in an average Egyptian government office works no more than 3 hours per day. [One] is shocked to find a woman clerk peeling vegetables at her desk to save time after she arrives home. In the same office, a male employee was shaving at a nearby desk to while away the boredom of office work. $^{7}$

In another instance Lengyel in a profound and perceptive analysis, attributes the dirty homes of a backward Egyptian village to either 'apathy caused by former oppression, or the heat of the sun.' 8

Other characteristics such as aggression, the emotionalism, and vagueness of thought are also attributed to Arabs. Says The Sun:

Divisions are among the Arabs with their dynastic feuds, emotional fantasies and religious fanaticism have always been good for a Western laugh...

\footnotetext{
2 H. Ellis, The Arab (Cleveland: The World, 1958), 15.

3 Ellis, The Arab, 18.

${ }^{4}$ G. Fichter, Iraq (New York: Watts, 1978), 24.

5 Fichter, Iraq, 24.

6 The Age, 4 January 1979.

7 E. Lengyel, Modern Egypt (New York: Watts, 1970), 70.

8 Lengyel, Modern Egypt, 60.
} 
Think of what those Arab oil royalties could achieve for human freedom if only Gaddaffi were a camel-driver and not a colonel. ${ }^{9}$

In another article The Age writes:

Dictatorial, absolutist rule by a monarch, a military strongman, or a religious charismatic leader is closer to Arab (and Moslem) tradition etc. ${ }^{10}$

(This complacent scorn is shared by the local theatre. In a play entitled 'An Evening's Intercourse', the only placard in the lobby making reference to a national community read 'Arabs use dunnies, please'.)

In brief, in the press as in other cultural forms of expression, specific images of lechery, stupidity, viciousness, veniality and blood thirstiness are commonplace. Arabs are always shown en masse in photographs; a people without individual characteristics or experience. Their posture, gestures, and other modes of non-verbal communication, show that they are eccentric and irrational.

Sáid sums it up when he notes:

An Arab oriental is that impossible creature whose libidinal energy drives him to paroxysms of over-stimulation - and yet, he is a puppet in the eyes of the world, staring vacantly out at a modern landscape he can neither understand nor cope with. ${ }^{11}$

In a more scholarly text, The Oxford Children's Reference Library Volume, the following definition of an Arab:

... he is a smooth shopkeeper... who pops out of his booth to persuade a foreigner to pay twice the value for his carpet or leather bag; the baggy trousered workman asleep on the corner of the pavement and not bothered at all whether he finishes his work today, tomorrow, or never; a peasant... who rides a donkey, while his wife, in a long black robe walks behind carrying bundles - All these are Arabs.

\section{Aggression, Economic Blackmail and Hostility with the West}

That Arab history and culture are studded with violence against itself and the West and that their emotionalism has swung Arabs back and forth between self-control and uncontrolled outbursts of temper, is nothing new.

On the in-built aggression of the Arabs, The Age begins an article with,

I and my cousins against the World, I and my brothers against my cousins, I against my brothers,

explaining that

... this old Arab saying indicates how fully aware the Arabs are of the propensity to conflict, a basic feature of their national character. ${ }^{12}$

About this one needs only to note that the saying alludes primarily to the inalienable allegiance which Arabs place to their immediate family before others. (The actual proverb reads: 'I and my brother against my cousin; and I and my cousin against the stranger').

\footnotetext{
9 The Sun, 26 February 1974.

10 The Age, 26 January 1980.

11 E. Sáid, Orientalism (London: Routledge and Keegan Paul, 1978), 312.

12 The Age, 26 January 1980.
} 
Table 2: Subject References of Moslem Arabs: January 1976 - December 1980

\begin{tabular}{|l|l|l|}
\hline Subject Reference & $\begin{array}{l}\text { No. of } \\
\text { Articles }\end{array}$ & $\%$ \\
\hline $\begin{array}{l}\text { Reference to race, culture, inter-or-intra-religio-political } \\
\text { conflicts }\end{array}$ & 102 & 24.3 \\
\hline $\begin{array}{l}\text { Reference to oil-wealth, economic blackmail and differences } \\
\text { with the West }\end{array}$ & 115 & 27.4 \\
\hline Islamic law and philosophy vs Christianity, Mohammed & 49 & 11.6 \\
\hline Women, sexual behaviour and marital relationships & 59 & 14.0 \\
\hline Arab-Israeli conflict - military, political and economic & 95 & 22.7 \\
\hline TOTAL & 419 & 100.0 \\
\hline
\end{tabular}

The trait of aggression is also exclusively attributed to Arabs: in The Shabby Sheikh, which is set in Australia, not Arabia, the villain is known as the shabby sheikh 'because he resembles a phoney Arab'. A few illustrations further reveal an ugly Australian in Arab clothing, riding a camel and tormenting others.

The Sun under the headline, 'The Koran and the Idiot Box' rhetorically exclaims:

When our media denounces the executions, mutilations and floggings and when we sneer at the affluence of oil-sheikhs, the Moslem world gives us no credit for compassion or democratic outrage. ${ }^{13}$

Indeed, since 1973 the image became associated with a threatening sheikh, standing behind a gasoline pump. Arabs have become the cause of gasoline shortages. They have become a disrupter of serene living and, subsequently, are denounced in a predictable range of reactions, such as that they are a threat to the free democratic existence of the West. Indeed one of the most often-asked questions is: how can the possessions of such vast oil wealth be justified in view of Arab 'unworthiness' and 'volatility'? As Gilford expressed it:

... [A]nd it was the oil rich Arab countries of Saudi Arabia, Iran [definitely a non-Arab country], Libya and others who stopped the shipment of their oil to the United States. It was a boycott that practically crippled the economics of most Western nations. ${ }^{14}$

Indeed little is said of previous decades when the Western oil companies were in the ascendancy. Instead, Arabs are portrayed as war-mongers, psychologically incapable of making peace. Adds Guilford:

The Syrians are a militant people. Their country may be poor, but they have powerful allies. They are backed by the Soviet Union. ${ }^{15}$

The only salvation now for the Arabs was to sublimate a generic form of aggression to match the civilization of Anglo-Saxons. This could only be done if the former comes to terms with the latter. Only by a cultural dependence on the West can they be cured of their idleness and misery:

\footnotetext{
13 The Sun, 16 April 1980.

${ }^{14}$ H. Guilford, Syria (London: Watts, 1978), 54.

15 Guilford, Syria, 54.
} 
Basically, Saudi Arabia and most other Arab countries are at grips with the problem that many foreigners regard as potential dynamite.

In blunt terms preservation of [Arab] Islamic traditionalism so far has been incompatible with modern ways brought by foreign technology and development. ${ }^{16}$

The West is still portrayed as the creator of social justice and true democracy:

In schools of missionaries particularly those of Britain and the U.S., Arab boys and young men learned for the first time something of the principles of liberty and justice, both for the individual and the nations. These principles provided the spark which the Arabs needed to turn their thoughts towards freeing their homeland from the Turks. ${ }^{17}$

And subsequently the only way that Arabs can be grateful, according to Ellis is by learning to trust the peoples of the West, whom they grew to distrust during the mandate period. ${ }^{18}$

\section{Women, Sex and Intra-Marital Relationships}

An obsession with 'lechery' of Arabs is found throughout the literature. They are belittled as creatures who express an inherited aggressiveness through a preoccupation with sexual power. There are numerous hints in press that Arabs are dominated by neurotic sexuality; by dominant instincts and passions; and by their religion. Notes the author of the Oxford Children's Reference Book:

In some parts of the Arab world if a girl is thought to have behaved badly, her brother may kill her, and the neighbours will admire him for doing his duty.

The women usually take the lion's share of such scathing remarks. In one instance Ellis remarks:

Poets have sung about the beautiful eyes of young Egyptian women, almond-shaped, with long eyelashes, and an exquisitely soft, bewitching expression... Unfortunately, this flowering beauty fades quickly under the strong Egyptian sun and hard household work. Few marks of beauty remain in older women. ${ }^{19}$

Practices mistakenly identified with the teachings of the Koran are commonly referred to in the press and elsewhere. Some of these include the veiling of women whenever they leave the house, the prohibition of photographs save those meant for passports, and the holding of a driving licence. ${ }^{20}$ Berger observes:

An Arab husband, for example, can divorce his wife just by saying to her before a witness, 'Ma Aridish' [I divorce thee] three times. ${ }^{21}$

Predictably Berger fails to stress that the legal procedure in such a case is actually more complicated that civil divorce in the West.

Some items are concerned only with trivia; the tone is well expressed in their headline: viz., 'Touch a Moslem woman and you die: Ali.'22

Needless to say, Arab and Anglo-Saxon cultures are polarized on the issue of sex; the emphasis of the former on the value of chastity is not understood by Australians. Moreover, though Arab Islamic law, like Christianity, generally prohibits homosexuality, the culture does tolerate males displaying affection to each other by holding hands, which is anything but evidence of homosexuality.

\footnotetext{
16 The Sun, 25 November 1979.

17 Ellis, The Arab, 106.

18 Ellis, The Arab, 115.

19 Ellis, The Arab, 63.

20 See The Australian, 27 September 1975.

21 G. Berger, Kuwait and the Rim of Arabia (New York: Watts, 1978), 12.

22 The Age, 29 September 1975.
} 


\section{Mohammed, Islam and Religious Fanaticism}

Unaccustomed to dealing with the Islamic faith, the press has difficulty in interpreting it. It continues to use the Western idea of the Koran as a mirror in interpreting cultural aspects of the Moslem community in both Australia and the Middle East. As a consequence, where the Moslem community gives prominence to its religion, its members are immediately described as fanatics and medieval throw-backs. The question remains, on what basis are such judgements made?

On scrutinizing items on Islam it is apparent that its overall treatment is based less on nationality than on religion. Islam is fundamentally seen as an anti-Christian ideology, the hostility of which reflects its inability to transcend an historical hibernation. ${ }^{23}$ Australians are still under the belief that Islam (a desert religion) and Christianity are still locked into war over the holy land because of a long-standing threat to invade the West. The following letter adequately supports the observation:

In his letter Sheikh Fehmi El-Imam said: 'It is impossible to find in the Holy Koran one single word of contempt against Christ.'

As an Anglo-Saxon, I dispute this claim. While Moslem religious books do not mention Christ, the Koran does and it mentions him to deny utterly His claim to be the Son of God. Other religions are, in fact, incompatible with Christ claims, but Mohammedanism rejects his claim pro forma. On the surface they are non-Christian whereas Islam is anti-Christian. Therefore as a religion it is peculiarly and emphatically under the ban of God as the Father of the Lord Jesus Christ, and is equally under the blighting influence of God's enemy, the Devil ...24

The range of headlines expressing a hostile tone was impressive: including 'Oil For the Lamps of Koran', 'The Sword of Islam', 'Mahomet Down Under', 'The Moslems Are Coming', 'The Koran And The Idiot Box'. 'Islamic Tide Runs High', 'Moslems in Confusion', 'Islam On The March Again', 'Holy War In Car Plant'.

A prominent feature of Islam, in fact, is the political diversity of regimes which consider themselves Moslem. For instance, the polarization of governments of Libya and Saudi Arabia is perhaps as intense as that between the Soviet Union and the United States. But the contrary is featured in the press. Writes The Australian:

Almost 8 centuries after the last major Crusade in 1201, the Islamic revolution is threatening world peace. Without the presence of oil the Islamic crises in the Middle East would really be of minor concern - but it is a vital commodity that a tyrant can command the support of either East or West. ${ }^{25}$

Indeed, Al-jihad or Holy War is viewed as being directed against three enemies: Christianity, Judaism and Islamic heretics. The press, however, refrained from making explicitly hostile statements against Moslems; the admission is, according to Sáid:

Of course Moslems are not anti-semitic like Nazis were, but their religion can too easily accommodate itself to anti-semitism and has done so. Similarly with regard to Islam and racism, slavery, and other more or less 'Western evils.' 26

The Sun commented:

But Moslems have one secret weapon, they multiply. Their numbers are rising three or four times as fast as the Soviet average. By the year 2000 one third of all new recruits to the Red Army will be Moslem ...27

\footnotetext{
23 Sáid, Orientalism, 317.

24 The Sun, 26 October 1979.

25 The Australian, 22 November 1979.

26 Sáid, Orientalism, 317.
} 
The press calls the religion of Islam 'Mohammedan', which is both a misnomer and an insult to Moslems, since it invites the charge of imposter, and gives the impression that they worship Mohammed. On the other hand, the insult might be deliberate. Under the headline 'Making a mountain out of Mohammed', The Age features extracts of a letter by Mr M. Khan objecting to calling a race horse 'Mohammed'.

It is an act of disrespect and improper for anyone to name an animal after His name. For instance if someone named a race horse 'Jesus Christ' don't you think it would offend millions of Christians throughout the world?28

Insensitivity to other Islamic cultural and religious matters was clearly brought out during a 'Dryland Farming Congress' in Adelaide on August 25, 1980. Roast pork was served to Arab Moslem delegates from the Middle East, and 24 songs from 24 countries, including that of Israel were played; none of them was Arab. ${ }^{29}$

In another item objecting to a proposal for Victoria's first Islamic school, The Herald quotes a local resident:

We are not going to let this happen. It will create a traffic hazard and it would be a health hazard to have another couple of hundred people inside my driveway ... and they abuse you. ${ }^{30}$

Another resident is quoted a saying:

When they come out, it's bedlam. They go down the street, buy soft drinks and food and don't mind where litterbugs from 1000 years of throwing it around in the desert $\left(\right.$ sic) ${ }^{31}$

Lengyel expresses the same attitude:

The strangest of all [to non-Moslems] is the month-long festival of Ramadan ... When Ramadan is over, the people act as if they were freed of chains. ${ }^{32}$

As the press stresses the differences between the Anglo-Saxon and Moslem communities, it continues to regard Moslem culture as threatening to the Australian way of life. Overall, Moslems are treated as an undifferentiated mass. Alternatively, the Islamic faith is judged by the actions of individuals who have violated the Anglo-Saxon code of ethics and the legal status quo. It should be emphasised that neither all Arabs are Moslem, nor are all Moslems Arabs; in Egypt alone there are six million Christians.

Table 3: Frequency of Associating the Labels 'Migrant,' 'Moslem' or a Specific Nationality with Arab-Australians: January 1976 - December 1980

\begin{tabular}{|l|l|l|}
\hline Type of Label & Frequency & \% \\
\hline 'Moslem' & 375 & 66.2 \\
\hline 'Migrant' & 65 & 11.2 \\
\hline Nationality as specified (eg. Egyptian) & 128 & 22.6 \\
\hline TOTAL & 566 & 100.0 \\
\hline
\end{tabular}

\footnotetext{
27 The Sun, 4 March 1977.

28 The Age, 17 August 1977.

29 The Herald, 28 August 1980.

30 The Herald, 19 April 1980.

31 The Herald, 19 April 1980.

32 Lengyel, Modern Egypt, 72.
} 
The fact that press articles on Islam are written by Western journalists reveals that Moslems are never allowed to speak for themselves. The only letter in defence of Islam appears in The Herald; it read:

I refer to the letter of N.J. Beardsworth (9.6.80). N. Beardsworth states that the Christian religion is constantly adapting and progressing. No N. Beardsworth, you no longer burn witches, but there are those who, while pertaining to the Christian faith will rape, murder, steal, cheat and break any or all of the Christian commandments. Can you honestly say in your assured ignorance, the people of Islam need to see the alternatives and the world will be better? ${ }^{33}$

Whilst the writer admits to the scanty proportion of educated Arabs in Australia, this should not however be a barrier to writing more favourably about their culture and religion.

\section{The Arab-Israeli Conflict}

Of all the parties involved in the 33 years conflict between the Arab countries and Israel, the Palestinian refugees receive the least amount of sympathy, though, admittedly, considerably more in textbooks than in the press. Ellis characterises the partiality of treatment:

In May 1948, the armies of Lebanon, Syria, Jordan, Iraq and Egypt invaded Palestine with the aim of driving the Jews into the sea ... The Arabs had long claimed that the land was theirs. They represented a force about one hundred times larger than that of young Israel. Yet Israel defeated Arabs. How? The Israelis were better trained, better fed, better educated, and more determined. To fight modern warfare soldiers cannot be ignorant. Why should the Egyptian soldiers have had their hearts in a war that they knew in advance could not help them to eat more or live better? ${ }^{34}$

Indeed, the word Palestinian is rarely mentioned. They are described as Arabs who fled their homes. ${ }^{35}$

A small number of textbooks examined erroneously state that the United Nations resolutions of November 1947 to the Partition of Palestine, the U.N. violated another principle of self-determination whereas in fact Arab governments have provided permanent settlements for most Bedouins, who make up less then 9 percent of all Arabs. ${ }^{36}$ Guilford quotes only part of the resolution with regard to the creation of Israel, and falsely states that the Arabs maintain that Palestine is Arab-Moslem and does not belong to Israeli. ${ }^{37}$ In brief, despite instances of sensitivity by the press, especially The Age, to the Palestinian refugee problem, the overall reporting is far from impartial.

\section{Conclusions}

The first point to be made is that only 12 percent of the items analysed make positive references to Arab-Moslems.

The overall image of Arabs and Moslems generally in both the press and textbooks is not the product of scholarly research. Instead of being non-manipulative and progressive, it depends on misrepresentation of the realities of Arab culture: its people, customs,

\footnotetext{
33 The Herald, 13 June 1980.

34 Ellis, The Arab, 13.

35 Guilford, Syria, 53.

36 Al-Qazzaz (1978), 455.

37 Guilford, Syria, 300.
} 
language and, above all, religion. Islam is viewed as a religion that is marked by a refusal to come to terms with Anglo-Saxon mores. Their differences are constantly emphasized: the latter is portrayed as rational, developed humane and superior; the former is psychotic, unbalanced, skilled only at self-defeating rhetoric. It is as Said $(1978, p 300)$ notes, seen as something to be 'feared or controlled'. ${ }^{38}$

It is thus argued that the press does not reflect the reality of events which surround them. Through selection and deletion, the public has become exposed to mere stereotypes. The image thus is one of backward, unshaven, fanatic, robe-covered, oil-rich, lecherous desert-dwellers. Such an image, also portrayed in textbooks, ultimately engenders contempt for Moslem Arabs.

\section{Acknowledgement}

The author wishes to acknowledge the financial support provided for this study by the Department of Immigration and Ethnic Affairs. This research originally appeared in the Australian Journal of Social Issues.

Author: Abe W Ata was born in Bethlehem. He was a delegate at the United Nations in 1970. His latest 12th publication is 'Mixed Marriages: Catholic/Non-Catholic Marriages in Australia' (David Lovell, July 2005). Dr Ata (or Abe) is a Senior Fellow at the Australian Catholic University in Melbourne.

Email: $\underline{\text { a.ata@patrick.acu.edu.au }}$

\footnotetext{
${ }^{38}$ Guilford, Syria, 300.
} 